\title{
DAMPAK OBYEK WISATA PANTAI PASIR PUTIH SITUBONDO TERHADAP PELUANG BEKERJA DAN BERUSAHA
}

\section{The Impact of Pasir Putih Beach's Tourism, Situbondo, on Job and Business Opportunities}

\author{
Afiefah Muthahharah ${ }^{1)}$, Soeryo Adiwibowo ${ }^{1)}$ \\ ${ }^{1)}$ Departemen Sains Komunikasi dan Pengembangan Masyarakat, Fakultas Ekologi Manusia, \\ Institut Pertanian Bogor, Darmaga Bogor 16680, Indonesia \\ Email:afiefahmuthahharah@gmail.com; s_adiwibowo@apps.ipb.ac.id
}

\begin{abstract}
The objective of this research is to analyze the impact of Pasir Putih Beach's tourisms on job and business opportunities. The results show that, first, tourism at Pasir Butih Beach strongly promote job and business opportunities for local i.e. hotel and homestay, boat rental, restaurants, peddlers, retailers, and packman. Second, with regards to full job in tourism sector, the economic contribution of tourism to total household income is quite significant. The average monthly income of the rental boatman could reach 69.3 percent (or Rp 859 700) of the total monthly income. Meanwhile for the peddler the contribution of tourism sector to the total household income reach 73.1 percent (or $R p 544$ 400). As for merchandise, the contribution from tourism reaches 50.3 percent (or $R p 455500)$ out of the total household income.
\end{abstract}

Keyword: tourism, job opportunity, business opportunity, and household income

\begin{abstract}
ABSTRAK
Penelitian ini menganalisis dampak obyek wisata pantai Pasir Putih Situbondo, Jawa Timur, terhadap peluang bekerja dan berusaha. Hasil penelitian menunjukkan, pertama, kegiatan pariwisata membuka peluang usaha dan bekerja di bidang (i) akomodasi, yaitu hotel dan penginapan; (ii) jasa transportasi, yaitu ojeg perahu; (iii) jasa rumah makan/kuliner; (iv) pedagang, yaitu sebagai pedagang kaki lima di kawasan pantai, pedagang keliling, dan pedagang yang membuka kios. Kedua, kontribusi pendapatan dari sektor pariwisata ini tergolong dominan. Pendapatan per bulan pengusaha ojeg perahu dari pariwisata mencapai 69.3 persen (atau Rp 859 700) dari total pendapatan rumahtangga. Adapun pendapatan per bulan pedagang kaki lima dari pariwisata mencapai 73.1 persen (Rp 544 400) dari total pendapatan rumah tangga. Sementara pendapatan per bulan usaha kios cinderamata dari pariwisata mencapai 50.3 persen ( $\mathrm{Rp} 455500$ ) dari total pendapatan rumahtangga.
\end{abstract}

Kata kunci: pariwisata, peluang bekerja, peluang berusaha, pendapatan 


\section{PENDAHULUAN}

Indonesia merupakan negara kepulauan yang memiliki panjang garis pantai sekitar $104.000 \mathrm{~km}$ dan jumlah pulau sebanyak 17.504 pulau. Dasar laut Indonesia memiliki topografi dasar laut yang tidak dimiliki negara lain, hal ini menjadikan lautan Indonesia memiliki keanekaragaman hayati terbesar di dunia dengan memiliki 8500 spesies ikan, 555 spesies rumput laut, dan 950 spesies biota terumbu karang (KKP 2008). Keanekaragaman hayati ini menjadi keunikan dan menambah keindahan laut Indonesia. Keindahan laut Indonesia dapat dijadikan sebagai potensi pembangunan. Pariwisata dapat dijadikan sebagai pilihan untuk meningkatkan perekonomian Indonesia yang masih dalam taraf negara berkembang. Kepariwisataan telah diatur di dalam Undang-undang Republik Indonesia Nomor 10 Tahun 2009. Pasal 1 menyebutkan bahwa pariwisata adalah berbagai macam kegiatan wisata dan didukung berbagai fasilitas serta layanan yang disediakan oleh masyarakat, pengusaha, Pemerintah, Pemerintah Daerah. Penyediaan fasilitas dan layanan ini tentu menciptakan peluang usaha bagi masyarakat sekitar. Sesuai dengan bunyi Pasal 3, yaitu Kepariwisataan berfungsi memenuhi kebutuhan jasmani, rohani, dan intelektual setiap wisatawan dengan rekreasi dan perjalanan serta meningkatkan pendapatan negara untuk mewujudkan kesejahteraan rakyat (UU RI 2009).

Bagi Indonesia pembangunan pariwisata juga memiliki kontribusi yang signifikan dalam pembangunan ekonomi nasional sebagai instrumen peningkatan perolehan devisa. Perolehan devisa dari kehadiran wisatawan mancanegara ke Indonesia dalam beberapa tahun terakhir ini melampaui aliran pemasukan devisa baik dari hutang luar negeri pemerintah maupun dari penanaman modal asing. Prospek yang sangat strategis pada sektor pariwisata tersebut tentu menjadi peluang yang sangat berarti bagi Indonesia sebagai suatu negara yang memiliki kekayaan alam dan budaya yang sangat besar. Sektor pariwisata yang telah berperan sebagai penyumbang devisa terbesar kedua setelah migas (Bappenas 2012) menjadi industri atau sektor penting yang dapat diandalkan pemerintah ke depan untuk menjadi pilar utama pembangunan ekonomi nasional.
Dilihat dari segi positifnya, dengan berkembanganya sebuah kawasan pariwisata yang dirasakan oleh masyarakat di sekitar objek wisata adalah suatu keuntungan, terutama dari segi materi; yaitu dapat meningkatkan pendapatan masyarakat sekitar objek wisata. Keuntungan yang lain dengan berkembangnya objek pariwisata adalah dibangunnya sarana dan prasarana yang memudahkan menuju lokasi wisata, misalnya transportasi, penginapan, kios-kios cinderamata dan lain sebagainya. Selain itu, masyarakat sekitar juga akan terbuka wawasannya tentang dunia luar, karena interaksi yang berlangsung antara penduduk setempat dengan para wisatawan asing ataupun domestik.

Salah satu obyek pariwisata bahari yang menjadi tempat wisata andalan Jawa Timur adalah Pantai Pasir Putih Situbondo. Pantai Pasir Putih yang berjarak kurang lebih $23 \mathrm{~km}$ disebelah barat Situbondo. Pasir putih terkenal dengan pantainya yang landai dan berpasir putih. Pada tahun 19601970 an masih banyak habitat laut yang bisa ditemukan di pantai ini. Kuda laut dan batu karang cantik berwarna warni banyak dijual di akuarium penjual ikan hias setempat. Wisatawan disuguhi pemandangan alam yang begitu menawan dan fasilitas untuk melakukan olahraga air seperti selancar angin, ski air, dan sepeda air. Selain fasilitas olahraga air, wisatawan juga dimanjakan dengan fasilitas penginapan yang cukup mewah, ada cottage sebagai penginapan dan beberapa jenis rumah tinggal lainnya.

Perubahan-perubahan dalam kehidupan sosial ekonomi masyarakat dapat terjadi sebagai akibat hadirnya sektor pariwisata di Pantai Pasir Putih Situbondo. Adanya kegiatan pariwisata telah memunculkan suatu bentuk peluang usaha dan kerja di daerah ini. Pantai Pasir Putih memiliki potensi yang mengandung nilai ekonomi yang berdampak pada kesejahteraan masyarakat yang berada di sekitar kawasan serta berguna membantu masyarakat yang ada di sekitar kawasan wisata agar lebih menyadari pentingnya lokasi wisata bagi peningkatan perekonomian masyarakat lokal dan mendorong masyarakat untuk turut melindungi kawasan tersebut. Adanya berbagai kegiatan di kawasan ini membuat peluang masyarakat dalam bidang ekonomi pun menjadi terbuka dan membuat masyarakat sekitar melakukan alternatif pekerjaan untuk menambah penghasilan rumah tangga mereka. Oleh karena itu, berdasarkan pemaparan 
dari latar belakang, peneliti ingin menganalisis dampak kawasan wisata Pantai Pasir Putih Situbondo terhadap peluang bekerja dan berusaha.

Berdasarkan latar belakang yang telah diuraikan, maka tujuan penelitian ini adalah:

1. Mengidentifikasi peluang bekerja dan berusaha yang tumbuh di obyek wisata Pantai Pasir Putih Situbondo;

2. Menganalisis pengaruh pemanfaatan peluang bekerja dan berusaha di kawasan wisata Pantai Pasir Putih terhadap pendapatan rumahtangga pelaku usaha

\section{PENDEKATAN TEORITIS}

Pariwisata adalah perpindahan sementara yang dilakukan manusia dengan tujuan keluar dari pekerjaan-pekerjaan rutin, keluar dari tempat kediamannya. Aktivitas dilakukan selama mereka tinggal di tempat yang dituju dan fasilitas dibuat untuk memenuhi kebutuhannya (Marpaung 2002). Mathieson dan Wall (1982) menyebutkan pengertian pariwisata yaitu perpindahan yang bersifat sementara menuju ke suatu tujuan yang berada di luar rumah dan tempat kerja yang normal, aktivitas dan fasilitas yang disediakan selama tinggal di tempat wisata dibuat untuk memenuhi kebutuhan dari wisatawan.

Marpaung (2002) mengelompokkan jenis obyek dan daya tarik wisata ke dalam dua kategori, yaitu : a) Obyek dan Daya Tarik Wisata (ODTW) alam, meliputi pantai, wisata bahari, pegunungan, daerah terpencil dan liar, taman dan daerah konservasi, health resort. Keindahan alam memiliki daya tarik yang sangat besar bagi wisatawan. Dengan melakukan berbagai aktivitas seperti snorkeling, diving, dan aktivitas lain yang bersentuhan langsung dengan alam, dapat memberikan kepuasan tersendiri untuk merelaksasikan diri sejenak dari pekerjaan rutin.

b) Obyek dan Daya Tarik Wisata (ODTW) sosial dan budaya, meliputi peninggalan sejarah kepurbakalaan dan monumen, museum dan fasilitas budaya, pola kehidupan, desa wisata, wisata keagamaan dan etnis. Wisata budaya ini dilakukan untuk mempelajari adat istiadat, perilaku, serta cara hidup masyarakat tradisional. Aktivitas seperti ini memberikan esensi yang berbeda dari perjalanan wisata pada umumnya karena wisatawan dapat berinteraksi langsung dengan masyatakat lokal serta ikut terlibat dalam kegiatan mereka, misalnya upacara adat, pertunjukan tari, dan sebagainya.

Yoeti (2008) mengungkapkan bahwa berdasarkan kacamata ekonomi makro, pariwisata jelas memberikan dampak positif, karena pariwisata sebagai suatu industri, dapat:

1. Menciptakan kesempatan berusaha dengan datangnya wisatawan, perlu pelayanan untuk menyediakan kebutuhan (need), keinginan (want), dan harapan (exception) wisatawan yang terdiri berbagai kebangsaan dan tingkah lakunya.

2. Meningkatkan kesempatan kerja (employment).

3. Meningkatkan pendapatan sekaligus mempercepat pemerataan pendapatan masyarakat, sebagai akibat multiplier effect yang terjadi dari pengeluaran wisatawan yang relatif cukup besar.

4. Meningkatkan penerimaan pajak pemerintah dan retribusi daerah.

5. Meningkatkan pendapatan nasional atau Gross Domestic Bruto

6. Mendorong peningkatan investasi dari sektor industry pariwisata dan sektor ekonomi lainnya

7. Memperkuat neraca pembayaran. Bila neraca pariwisata mengalami surplus, dengan sendirinya akan memperkuat neraca pembayaran Indonesia, dan sebaliknya.

Selain memiliki dampak positif dari segi ekonomi, pariwisata juga memberi dampak negatif sebagai akibat pengembangan pariwisata secara tidak terkendali. Seperti:

1. Harga tanah menjadi mahal, pantai-pantai dikaveling, sehingga sering terjadi spekulasi harga yang pada akhirnya meningkatkan harga tanah di sekitarnya.

2. Harga-harga bahan makan di pusat-pusat konsentrasi kegiatan pariwisata menjadi mahal yang dapat meningkatkan inflasi tiap tahunnya.

3. Sumber-sumber hayati menjadi rusak, yang menyebabkan Indonesia kehilangan daya tariknya untuk jangka panjang

4. Terjadi urbanisasi, pencari kerja mengalir dari desa ke kota-kota besar 
5. Ramainya lalu-lintas wisatawan, ternyata ditumpangi oleh penyelundupan obat bius dan narkotika

Menurut BPS dikutip Tando (1992), peluang usaha dan kerja dapat dibedakan atas usaha formal dan informal. Usaha informal adalah usaha tradisional yang lokasinya tidak tetap, tidak memakai bangunan dan jam kerja yang tidak teratur, mencakup usaha sendiri dan usaha dengan bantuan keluarga. Usaha formal merupakan usaha yang lokasinya tetap, menggunakan bangunan dan jam kerja yang teratur serta mencakup usaha dengan buruh tetap atau karyawan. Kegiatan informal merupakan kegiatan yang padat karya, tingkat produktivitas rendah, pelanggan yang sedikit, tingkat pendidikan formal yang rendah, penggunaan teknologi menengah, sebagian pekerja keluarga, mudah keluar masuk usaha, serta kurang dukungan dan pengakuan dari pemerintah. Menurut Breman dikutip Tando (1992) memberikan batasan usaha formal sebagai semua pekerja yang bergaji bulanan atau harian dalam suatu pekerjaan yang permanen, dan meliputi sejumlah pekerjaan yang saling berhubungan serta terorganisir dengan baik dan dilindungi badan hukum resmi.

BPS menurut Tando (1992) mengungkapkan bahwa penggunaan peluang usaha dan kerja dipengaruhi oleh faktor individu yaitu pendidikan, jenis kelamin, status perkawinan dan umur. Soentoro (1983) dikutip Tando (1992) menjelaskan bahwa seseorang yang mempunyai tingkat pendidikan rendah akan menempati sektor informal sedangkan yang berpendidikan agak tinggi cenderung memilih pekerjaan di sektor formal. Usaha formal pariwisata umumnya membutuhkan tenaga kerja dan berhubungan dengan pelayanan terhadap wisatawan (usaha penjualan jasa), sehingga sikap yang dibutuhkan dalam usaha pariwisata umumnya dimiliki oleh perempuan. Status perkawinan juga turut mempengaruhi dimana perempuan yang sudah menikah umumnya akan memanfaatkan peluang usaha yang tidak bertentangan dengan peran mereka sebagai ibu. Mereka yang sudah janda mempunyai kecenderungan tinggi untuk berpartisipasi dalam usaha atau kerja karena kesempatan mereka relatif lebih longgar baik alasan biologis, psikologis serta ekonomis. Motivasi memasuki lapangan kerja juga menentukan jenis pekerjaan yang ditekuni. Mereka yang janda cenderung memilih pekerjaan di usaha formal pariwisata (karyawan hotel, restoran atau guide) atau usaha informal sebagai pedagang yang berusaha sendiri. Bagi perempuan yang sudah kawin akan memilih pekerjaan yang dikerjakan sambil memainkan peranan sebagai ibu seperti berdagang asongan atau dengan bantuan keluarga. Bagi mereka yang belum kawin akan memilih pekerjaan yang dapat dikerjakan kapan dan dimana saja seperti menjadi karyawan hotel, restoran dan lain-lain.

Menurut Badan Pusat Statistik (2010) konsep pendapatan rumah tangga adalah seluruh pendapatan yang diterima oleh rumah tangga maupun pendapatan anggota-anggota rumah tangga. Pendapatan dapat berasal dari:

a) Balas jasa faktor produksi tenaga kerja, yaitu upah/gaji, keuntungan, bonus yang mancakup dari seluruh anggota rumah tangga yang bekerja sebagai imbalan bagi pekerjaan yang dilakukan

b) Balas jasa kapital, yaitu bunga, bagi hasil dari hasil usaha seluruh anggota rumah tangga

c) Pendapatan yang berasal dari pihak lain yaitu pendapatan diluar upah/gaji yang menyangkut dari : (i) perkiraan sewa rumah milik sendiri; (ii) bunga deviden; (iii) bukan hasil usaha; (iv) pensiunan; (v) kiriman dari famili/pihak lain secara rutin, ikatan dinas.

Scoones (1998) mengungkapkan strategi nafkah yang umumnya dilakukan oleh masyarakat pedesaan meliputi: (1) Rekayasa sumber nafkah pertanian, yang dilakukan dengan memanfaatkan sektor pertanian secara efektif dan efisien baik melalui penambahan input eksternal seperti teknologi dan tenaga kerja (intensifikasi), maupun dengan memperluas lahan garapan (ekstensifikasi); (2) Pola nafkah ganda (diversifikasi), yang dilakukan dengan menerapkan keanekaragaman pola nafkah dengan cara mencari pekerjaan lain selain pertanian untuk menambah pendapatan. Atau dengan mengerahkan tenaga kerja keluarga (ayah, ibu dan anak) untuk ikut bekerja -selain pertanian- dan memperoleh pendapatan; dan (3) Rekayasa spasial (migrasi) merupakan usaha yang dilakukan dengan melakukan mobilitas ke daerag lain di luar desanya, baik secara permanen maupun sirkuler untuk memperoleh pendapatan. 


\section{KERANGKA PEMIKIRAN}

Pariwisata merupakan salah satu sektor pembangunan yang dewasa ini sedang digalakkan oleh pemerintah dan mempunyai peran yang sangat penting dalam pembangunan di Indonesia. Salah satu kawasan pesisir yang mempunyai potensi sumberdaya dan dapat mendukung kegiatan pariwisata adalah Pantai Pasir Putih Situbondo. Hadirnya kegiatan pariwisata akan menyebabkan adanya permintaan sarana dan prasarana yang dibutuhkan oleh wisatawan seperti : penginapan, rumah makan, transportasi, perdagangan, dan jasa. Kebutuhan-kebutuhan tersebut merupakan peluang usaha atau kerja terutama bagi masyarakat di kawasan obyek wisata. Bentuk peluang usaha dan kerja dapat dibedakan berdasarkan sifatnya (formal dan informal), berdasarkan jenis kegiatan (rumah makan, transportasi, perdagangan) serta berdasarkan pola kegiatan (kegiatan yang dilakukan setiap hari atau kegiatan yang hanya dilakukan di akhir pekan, liburan atau musim kunjungan wisatawan). Pemanfaatan peluang usaha dan kerja juga dapat mempengaruhi pendapatan masyarakat yang memanfaatkan peluang tersebut yang dapat dilihat dari rata-rata pendapatan usaha atau kerja

\section{Hipotesis Penelitian}

Berdasarkan kerangka pemikiran diatas, maka dapat ditarik hipotesis penelitian yaitu:

1. Obyek wisata Pantai Pasir Putih membuka aneka peluang bekerja dan berusaha yang dapat dimanfaatkan oleh masyarakat sekitar Desa Pasir Putih

2. Pemanfaatan peluang bekerja dan berusaha di obyek wisata pantai pasir putih meningkatkan pendapatan warga masyarakat Desa Pasir Putih

\section{METODE PENELITIAN}

Penelitian ini dilakukan di obyek wisata Pantai Pasir Putih Situbondo. Pemilihan lokasi dilakukan secara purposive yang disesuaiakan dengan karakteristik dan data yang dibutuhkan oleh peneliti. Waktu penelitian dilaksanakan selama dua minggu, yaitu pada minggu keempat bulan Februari 2015 hingga minggu pertama bulan Maret 2015. Metode peneltiian yang digunakan adalah pendekatan kuantitatif yang didukung data kualitatif. Pengolahan data kuantitatif menggunakan aplikasi Microsoft Excel 2010 berupa tabel frekuensi, dan data kualitatif dikumpulkan, dianalisis, direduksi, dan disajikan untuk menjelaskan dan mempekuat analisis dari data kuantitatif.

\section{HASIL DAN PEMBAHASAN}

Kabupaten Situbondo merupakan salah satu Kabupaten di Jawa Timur yang cukup dikenal dengan sebutan Daerah Wisata Pantai Pasir Putih yang letaknya berada di ujung timur pulau Jawa bagian utara dengan posisi pada lintang $7^{\circ} 35^{\prime}-7$ ${ }^{\circ} 44^{\prime}$ LS (Lintang Selatan) dan $113^{\circ} 30^{\prime}-114^{\circ} 42^{\prime}$ BT (Bujur Timur). Sedangkan Pasir Putih terletak pada jalan Surabaya-Situbondo pada kilometer 171-174 atau jarak 21 kilometer ke arah barat dari Ibukota Situbondo yang meliputi kawasan pantai sepanjang 3 kilometer, dengan lebar rata-rata 90100 Meter dari garis pasang pantai.

Daerah penelitian yaitu Desa Pasir Putih merupakan salah satu desa bagian dari Kecamatan Bungatan memiliki batas-batas sebagai berikut:

a. Sebelah utara berbatasan dengan Laut Jawa

b. Sebelah barat berbatasan dengan Desa Klatakan

c. Sebelah selatan berbatasan dengan Gunung Ringgit dan Hutan Jati

d. Sebelah timur berbatasan dengan Desa Bungatan

Kecamatan Bungatan mempunyai luas wilayah $66,07 \mathrm{~km}^{2}$ (Pemerintah Daerah Situbondo, 2013), sedangkan Desa Pasir Putih yang merupakan bagian wilayah dari Kecamatan Bungatan mempunyai luas $18,09 \mathrm{~km}^{2}$ yang terbagi atas 6 dusun yaitu Dusun Krajan, Tegal Mulyo, Pandan Sari, Kembang Sambi Barat, Kembang Sambi Timur dan Pecaron.

Desa Pasir Putih memiliki luas wilayah sebesar $18.09 \mathrm{~km}^{2}$ yang terdiri dari 12 Dusun dan 1162 Kepala Keluarga, berdasarkan data monografi Kecamatan Bungatah Tahun 2013, penduduk Desa Pasir Putih tercatat sejumlah 3647 jiwa, dengan proporsi laki-laki 1785 jiwa dan perempuan 1862 jiwa.

Penduduk Desa Pasir Putih terkenal dengan mata pencahariannyya sebagai pengrajin kerang. Hal ini mengingat bahwa lokasi Desa Pasir Putih yang letaknya berdekatan dengan Pantai Pasir Putih menjadikan desa ini menjadi sangat strategis 
sebagai lokasi usaha kerajinan kerang. Usaha kerajinan kerang ini juga merupakan salah satu sarana untuk mewujudkan kesejahteraan ekonomi masyarakat. Pekerjaan sebagai pengrajin kerang merupakan pekerjaan di sektor informal yang banyak ditekuni masyarakat Desa Pasir Putih. Tidak hanya sebagai pengrajin kerang, masyarakat Desa Pasir Putih juga memiliki jenis pekerjaan yang beragam. Kondisi pendidikan masyarakat Desa Pasir Putih sebagian besar masih tergolong rendah yakni belum menempuh pendidikan wajib 9 tahun mengakibatkan cukup rendahnya kualitas sumberdaya manusia yang tinggal di Desa Pasir Putih. Tingkat pendidikan yang masih tergolong rendah menyebabkan masyarakat mengalami keterbatasan dalam mengakses peluang kerja.

Adanya kegiatan pariwisata di Pasir Putih membuka banyak lapangan pekerjaan. Masyarakat lokal maupun dari berbagai daerah berdatangan ke kawasan wisata untuk membuka usaha dan bekerja. Jumlah kunjungan wisatawan yang meningkat juga turut memicu terjadinya peningkatan aktivitas usaha. Jenis-jenis usaha yang tumbuh akibat adanya Obyek Wisata Pantai Pasir Putih, diantaranya:

\section{1) Akomodasi}

Akomodasi di Obyek Wisata Pantai Pasir Putih berupa hotel yang dijadikan tempat menginap wisatawan. Menurut UPT Obyek Wisata Pantai Pasir Putih, terdapat empat hotel yang berada di sekitar kawasan pantai. Diantaranya; hotel, cafe dan restoran antara lain: Hotel, Cafe dan Restoran Sidomuncul-1, Hotel dan Cafe Mutiara, Hotel dan Cafe Papin Inn, dan Hotel dan Cafe Sidomuncul-2. Saat puncak kunjungan wisatawan, yaitu hari besar dan hari libur sekolah, seringkali terjadi lonjakan pengunjung sehingga beberapa rumah penduduk disewakan untuk memenuhi jasa penginapan. Fasilitas tiap hotel berbeda-beda, seperti tempat tidur atau kasur yang menyediakan extra bed, kamar mandi, rak handuk, air conditioner, kipas angin, televisi, dan dispenser. Fasilitas umum yang disediakan berupa kolam renang, pemandian air panas, cafe dan restoran, area bermain, dan live music. Tarif penginapan di Pasir Putih berkisar mulai harga Rp 80.000 sampai Rp 650.000.

\section{2) Jasa Perahu Wisata}

Jasa perahu wisata atau biasa dikenal dengan ojeg perahu, setiap harinya beroperasi sekitar \pm 45 perahu untuk mengantarkan wisatawan berkeliling melihat keindahan pantai. Tap perahunya memuat sekitar $4-8$ orang. Ada petugas yang bertugas untuk mengendarai perahu, dan satu orang lagi membantu untuk mengarahkan jalannya perahu. Biasanya pengunjung yang datang ke Pantai Pasir Putih ingin menikmati pemandangan pantai dengan berkeliling menggunakan perahu, karena salah satu keunggulan Pantai Pasir Putih Situbondo ada pada keindahan alam bawah lautnya. Pengunjung dapat menikmati keindahan alam tanpa perlu menyelam. Bagi pengunjung yang ingin menyewa perahu tradisional untu menyusuri perairan pantai dan menikmati pemandangan taman laut dikenakan biaya Rp 50000 per perahu untuk sekali jalan.

\section{3) Usaha Rumah Makan dan Jasa Kuliner}

Usaha pengelolaan jasa pangan banyak ditemui di obyek wisata jika musim liburan sekolah dan musim kunjungan tiba. Jika pada hari biasa yaitu hari senin sampai jum'at berkunjung ke obyek wisata akan sulit menemui jasa pangan yang berjualan di sekitar obyek wisata. Pada musim sepi kunjungan, biasanya para penjual makanan akan melakukan pekerjaan lain seperti pengrajin kerang, berdagang, atau bertani. Terdapat satu restoran besar di sekitar Pantai Pasir Putih yang menjadi sentra tempat makan pengunjung. Karena letaknya yang strategis, yaitu terletak di depan pintu masuk sebelah kiri, bersebelahan dengan mushalla menjadikan restoran ini ramai dikunjungi wisatawan. Jenis makanan yang dijual pun beragam, mulai dari nasi goreng, indomie, hingga aneka seafood. Harga yang ditawarkan memang relatif lebih mahal dibandingkan rumah makan berkisar antara 15000 hingga 50000 rupiah per jenis makanan. Selain restoran, ada juga enam rumah makan yang letaknya di pinggir jalan, rumah makan tersebut menjual aneka makanan ringan seperti snack, dan jajanan kue pasar, serta makanan berat seperti baso, nasi ayam, nasi rames, dan lainnya. Harga yang ditawarkan juga bermacam-macam, mulai dari 3000 hingga 15000 rupiah. Harga yang masih sangat terjangkau bagi pengunjung dan pengguna jalan.

\section{4) Pedagang}

Jenis pekerjaan di sektor informal yang ditemui di obyek wisata adalah Pedagang Kaki Lima (PKL) di sepanjang pantai, pedagang asongan/keliling. Sementara tidak terdapat data mengenai jumlah pedagang asongan/keliling atau PKL. Namun, jumlah pedagang asongan/keliling akan meningkat saat ramai kunjungan wisatawan seperti hari libur 
sekolah, libur hari besar, atau libur tahun baru. Sebagian besar PKL berjualan makanan dan minuman (kelapa muda, indomie, baso, kopi, sate dan lain-lain). Selain itu, ada pula yang berjualan ikan asin dan ikan segar yang bisa dibakar langsung di sekitar pantai.

\section{5) Kios Cinderamata}

Kios cinderamata merupakan sektor yang paling mendominasi di Pantai Pasir Putih, ada sekitar 36 kios yang beroperasi setiap harinya selama 24 jam. Cinderamata yang dijual merupakan hasil kerajinan tangan dari penduduk Desa Pasir Putih itu sendiri. Penduduk Desa Pasir Putih yang bekerja sebagai pengrajin kerang dalam setiap harinya membuat 20-50 kerajinan dari bahan dasar kerang. Jumlah kerajinan yang dihasilkan bisa berbeda-beda sesuai dengan tingkat kesulitan kerajinan tersebut. Kerajinan yang dihasilkan bervariasi seperti figura, jam dinding, aksesoris, hiasan, asbak, dan lainnya. Setiap pengrajin kerang mempunyai kreativitas yang beragam, sehingga hasil karya akan beragam pula untuk setiap pekerja pengrajin kerang. Selain itu, para pengrajin harus kreatif dalam membuat kerajinan supaya menghasilkan karya yang inovatif dan menarik perhatian konsumen atau wisatawan.

Keberadaan Obyek Wisata Pantai Pasir Putih terbukti memberikan kontribusi positif terhadap pendapatan rumah tangga masyarakat. Rata-rata pendapatan masyarakat yang bekerja di sektor pariwisata tiap bulannya berkisar Rp 455500 sampai Rp 909 300. Jumlah pendapatan tesebut rmasih jauh dibawah Upah Minimum Regional (UMR) Kabupaten Situbondo yaitu Rp 1231650. Selain itu, masyarakat juga memperoleh penghasilan tambahan dari sektor non-pariwisata, yang apabila ditotalkan akan memenuhi syarat UMR Kabupaten Situbondo. Namun, tidak semua masyarakat memanfaatkan sektor non-pariwisata sebagai sumber penghasilan tambahan.

Besar kecilnya pendapatan yang didapat oleh masyarakat sangat ditentukan oleh jumlah wisatawan yang berkunjung. Semakin banyak wisatawan yang berwisata ke Pantai Pasir Putih, maka semakin besar pula pendapatan yang diperoleh oleh pelaku usaha. Namun hal ini perlu kerjasama dari berbagai pihak, mulai dari Perusahaan daerah Pasir Putih, Kecamatan Bungatan, dan Pemerintah Kabupaten Situbondo untuk terus mengembangkan Obyek Wisata Pantai
Pasir Putih agar menarik perhatian pengunjung dan meningkatkan daya saing dengan obyek wisata lainnya di daerah Situbondo.

\section{SIMPULAN DAN SARAN}

\section{Simpulan}

Keberadaan Obyek Wisata Pantai Pasir Putih telah menciptakan lapangan pekerjaan bagi penduduk lokal. Berbagai lapangan pekerjaan yang tercipta ini dimanfaatkan dengan baik oleh penduduk lokal. Hal tersebut terlibat dari banyaknya penduduk lokal yang menguasai beberapa jenis pekerjaan (usaha) pariwisata. Usaha tersebut diantaranya seperti: (i) akomodasi, yaitu hotel dan penginapan; (ii) transportasi, yaitu ojeg perahu; (iii) usaha rumah makan dan jasa kuliner, yaitu rumah makan/restauran; (iv) pedagang, yaitu pedagang kaki lima di kawasan pantai, pedagang keliling, dan pedagang yang membuka kios di sekitar kawasan pantai.

Pemanfaat peluang usaha dan kerja pariwisata dominan menjadikan usaha dan kerja tersebut sebagai pendapatan (mata pencaharian) tunggal bagi mereka. Meskipun demikian, ada beberapa pelaku usaha yang melakukan pekerjaan sampingan untuk memperoleh pendapatan tambahan saat musim sepi kunjungan. Pendapatan pemanfaat usaha dan kerja pariwisata masih tergolong ke dalam tingkat pendapatan rendah. Hal ini dimungkinkan karena kunjungan wisatawan yang bersifat siklikal sehingga pendapatan di sektor wisata tidaklah menentu. Namun di saat akhir pekan atau di musim kunjungan wisata yang cukup tinggi seperti pada libur hari raya dan tahun baru, pendapatan para pengusaha dan pekerja pariwisata dapat meningkat drastis.

Dapat disimpulkan bahwa keberadaan obyek wisata Pantai Pasir Putih memberikan kontribusi positif bagi masyarakat yang memanfaatkan peluang bekerja dan berusaha yang terbuka. Dikalangan pengusaha ojeg perahu, pedagang kaki lima, dan usaha cinderamata, pendapatan dari pariwisata jauh lebih besar dari pada pendapatan dari luar pariwisata. Dikalangan pengusaha ojeg perahu, pendapatan rumahtangga per bulan dari pariwisata menyumbang 69.3 persen atau $\mathrm{Rp} 859$ 700 dari total pendapatan rumahtangga per bulan sebesar Rp 1234 700. Dikalangan pedagang kaki lima pendapatan rumahtangga per bulan dari 
pariwisata menyumbang 73.1 persen atau Rp 544 400 dari total pendapatan rumahtangga per bulan sebesar Rp 744 400. Sementara dari usaha kios cinderamata menyumbang 50.3 persen atau Rp 455 500 dari total pendapatan rumahtangga per bulan sebesar Rp 905500.

\section{Saran}

Terdapat beberapa saran terkait dengan hasil penelitian yang telah dilakukan, diantaranya yaitu:

1. Pemerintah Daerah Kabupaten Situbondo dan Perusahaan Daerah Pasir Putih sebaiknya melakukan pengelolaan kawasan pantai, khususnya dalam pengelolaan lingkungan pantai. Selain itu, perlu adanya aktivitas wisata yang dapat menarik perhatian pengunjung, seperti pertunjukan tari tradisional, festival kesenian daerah, sentra makanan khas daerah.

2. Perusahaan Daerah Pasir Putih dan masyarakat Desa Pasir Putih sebaiknya melakukan kerjasama dalam menjaga dan memelihara lingkungan pantai, seperti menjaga kebersihan pantai, memperbaiki sarana dan prasaran yang rusak, menambah sarana yang menunjang wisatawan untuk berlibur dalam waktu yang lama di Pasir Putih

3. Perlu diadakannya kegiatan bersih-bersih pantai dengan melibatkan semua petugas dan pelaku usaha didalam obyek wisata tersebut.

4. Perlu adanya upaya dari pihak pengelola obyek wisata untuk mencegah serta meminimalisasi timbulnya dampak negatid akibat kehadiran pengunjung, dengan cara meningkatkan pengawasan saat musim puncak kunjungan wisata

5. Perusahaan Daerah Pasir Putih hendaknya meningkatkan kegiatan promosi obyek wisata melalui sosial media untuk meningkatkan jumlah kunjungan wisatawan

6. Pemerintah Daerah Kabupaten Situbondo dan Perusahaan Daerah Pasir Putih sebaiknya melakukan kerjasama dalam penambahan area obyek wisata, menambah sarana dan prasarana, serta kegiatan yang mendukung. Seperti, camping area, outbond, dan sarana olahraga air

7. Bagi akademisi, perlu adanya penelitian lanjutan mengenai dampak Obyek Wisata Pantai Pasir Putih terutama aspek-aspek lain.

\section{DAFTAR PUSTAKA}

[BPS] Badan Pusat Statistik. 2010. Penduduk Indonesia tahun 2010. [Internet]. [dikutip 17 Januari 2015]. Dapat diunduh dari http://www.bps.go.id/hasil_publikasi/inkes ra2010

[UU] Undang-Undang Republik Indonesia Nomor 10 Tahun 2009 Tentang Kepariwisataan

Damanik, Janianton dan Helmut F. Weber. 2006. Perencanaan Ekowisata. Yogyakarta [ID] : Penerbit Andi

Dharmawan AH. 2006. Sistem Penghidupan dan Nafkah Pedesaan Pandangan Sosiologi Nafkah (Livelihood Sociology) Mazhab Barat dan Mazhab Bogor. Sodality. Jurnal Transdisiplin Sosiologi, Komunikasi, dan Ekologi Manusia. Bogor [ID]. I (2). Hal. 169-192

Marpaung H, dan H. Bahar. 2002. Pengantar Pariwisata. Bandung [ID] : Alfabeta. 212 hal

Mathieson A, dan G. Wall. 1982. Tourism : Economic, physical, and social impacts. Harlow [UK] : Longman

Nurmanaf AR. 1985. Pola Kesempatan Kerja dan Sumber Pendapatan Rumah Tangga di Pedesaan Jawa Barat. Bogor [ID] : Pusat Penelitian Agro Ekonomi

Pitana IG, dan PG Gayatri . 2004. Sosiologi Pariwisata. Yogyakarta [ID] : Andi, 200 hal

Sadono, Dwi, Adiwibowo S dan Dharmawan AH. 1992. Dampak Pariwisata terhadap Peluang Usaha dan Kerja Luar Pertanian di Pedesaan : Kasus di Daerah Wisata Palabuhan Ratu, Sukabumi, Jawa Barat. Bogor [ID] : Pusat Studi Pembangunan Lembaga Penelitian IPB

Samsuridjal, Kaelany. 1997. Peluang di Bandung Pariwisata. Yogyakarta [ID] : Mutiara Sumber Widya

Scoones I. 1998. Sustainable Rural Livelihoods: A Framework from Analysis. IDS Working Paper 72. [internet]. [dikutip tanggal 17 Maret 2015]. Sussex [UK]: Institut of Development Studies. Dapat diunduh dari: http://www.ids.ac.uk/files/dmfile/Wp72.pd $\underline{\mathrm{f}}$

Singarimbun M, dan E. Sofian. 1989. Metode Penelitian Survai. Jakarta [ID] : LP3ES. 336 hal. 
Suwantoro G. 1997. Dasar-Dasar Pariwisata. Yogyakarta [ID] : Andi, 108 hal

Tando S. 1992. Dampak Pengembangan Pariwisata terhadap Peluang Usaha atau Kerja Luar Pertanian : Suatu Pengamatan di Kelurahan Tikumna Malenong, Kecamatan Sanggalagi, Kabupaten Tana Toraja, provinsi Sulawesi Selatan. [Tesis]. Bogor [ID] : Program Pasca Sarjana IPB

Urry J. 1990. The Tourist Gaze : Leisure and Travel in Contemporary Societies. Sage Publications. 176 hal.

Yoeti OA. 1988. Pengantar Ilmu Pariwisata, Jakarta [ID]: Angkasa, 383 hal.

Yoeti OA. 2008. Ekonomi Pariwisata. Introduksi, Informasi, Implementasi. Jakarta [ID]: Kompas. 292 hal. 
Nadhira \& Sumarti / JSKPM 1(2): 157-166 